\title{
A Role for Cyclin-Dependent Kinase(s) in the Modulation of Fast Anterograde Axonal Transport: Effects Defined by Olomoucine and the APC Tumor Suppressor Protein
}

\author{
Nancy Ratner, ${ }^{1,3}$ George S. Bloom, ${ }^{2,3}$ and Scott T. Brady2,3 \\ ${ }^{1}$ Department of Cell Biology, Neurobiology, and Anatomy, University of Cincinnati School of Medicine, Cincinnati, Ohio \\ 45267-0521, 2Department of Cell Biology and Neuroscience, University of Texas Southwest Medical Center, Dallas, \\ Texas 75235-9111, and 3Marine Biological Laboratory, Woods Hole, Massachusetts 02543
}

Proteins that interact with both cytoskeletal and membrane components are candidates to modulate membrane trafficking. The tumor suppressor proteins neurofibromin (NF1) and adenomatous polyposis coli (APC) both bind to microtubules and interact with membrane-associated proteins. The effects of recombinant NF1 and APC fragments on vesicle motility were evaluated by measuring fast axonal transport along microtubules in axoplasm from squid giant axons. APC4 (amino acids 1034-2844) reduced only anterograde movements, whereas APC2 (aa 1034-2130) or APC3 (aa 2130-2844) reduced both anterograde and retrograde transport. NF1 had no effect on organelle movement in either direction. Because APC contains multiple cyclin-dependent kinase (CDK) consensus phosphorylation motifs, the kinase inhibitor olomoucine was examined. At concentrations in which olomoucine is specific for cyclindependent kinases $(5 \mu \mathrm{M})$, it reduced only anterograde trans- port, whereas anterograde and retrograde movement were both affected at concentrations at which other kinases are inhibited as well $(50 \mu \mathrm{M})$. Both anterograde and retrograde transport also were inhibited by histone $\mathrm{H} 1$ and KSPXK peptides, substrates for proline-directed kinases, including CDKs. Our data suggest that CDK-like axonal kinases modulate fast anterograde transport and that other axonal kinases may be involved in modulating retrograde transport. The specific effect of APC4 on anterograde transport suggests a model in which the binding of APC to microtubules may limit the activity of axonal CDK kinase or kinases in restricted domains, thereby affecting organelle transport.

Key words: cyclin-dependent kinases; olomoucine; axonal transport; NF1; microtubule; adenomatous polyposis coli; APC; CDK5
Molecular components destined for specific subcellular domains of a neuron must be targeted correctly, even when a presynaptic terminal or patch of membrane is a meter or more from sites of protein synthesis in the cell body. Remarkably, molecular mechanisms underlying the regulation of membrane trafficking remain mainly unknown (Thaler and Haimo, 1996).

Membrane-bound organelles (MBOs) are delivered to axonal domains by fast axonal transport (Brady, 1993). Polarized axonal microtubules, with plus ends facing the synapse and minus ends facing the soma (Burton and Page, 1981; Heidemann et al., 1981), traffic $\mathrm{MBO}$ in both anterograde and retrograde directions. Directionality is conferred by motor proteins such as kinesins and

Received June 8, 1998; revised July 20, 1998; accepted July 21, 1998.

This work was supported by grants from National Institutes of Health (NS28840) and the Department of Defense (to N.R.); by grants from National Institutes of Health (NS23868 and NS23320), NASA, National Institute on Aging (AG2-962/ AG12646), the Robert A. Welch Foundation (I-1237), and the Muscular Dystrophy Association (to S.B.); and by grants from National Institutes of Health (MS30485) and the Robert A. Welch Foundation (I-1236) (to G.B.). We thank Drs. Paul Polakis and Bonnee Rubinfeld of Onyx Pharmaceuticals (Richmond, CA) for the generous gift of recombinant APC polypeptides and Dr. Robin Clark for the generous gift of recombinant neurofibromin. We also thank Dr. Philip Leopold for advice on electron microscopy; Barry Gumbiner, Chris Trzepacz, Joanna Groden, and Craig Garner for helpful discussions; and Linda Parysek for a review of this manuscript. We thank Kim Selkoe, Melina Gould, and Alyssa Babcock for technical assistance and the University of Cincinnati for enabling N.R. to undertake experiments at Woods Hole.

Correspondence should be addressed to Dr. Nancy Ratner, Department of Cell Biology, Neurobiology, and Anatomy, University of Cincinnati School of Medicine, 231 Bethesda Avenue, Cincinnati, OH 45267-0521.

Copyright (ㄷ) 1998 Society for Neuroscience $\quad 0270-6474 / 98 / 187717-10 \$ 05.00 / 0$ dyneins (Brady, 1995; Brady and Sperry, 1995; Hirokawa, 1996) that interact with both microtubules and membranes to move organelles toward the plus or minus end of microtubules (Brady and Sperry, 1995). Mechanisms for modulating axonal transport may involve proteins that interact with microtubules, that bind membranes or membrane proteins, or that are components of signaling pathways.

In adult neurons all three characteristics are expressed by two tumor suppressor proteins: the neurofibromatosis type 1 (NF1) gene product, neurofibromin (Viskochil et al., 1990; Wallace et al., 1990), and the familial adenomatous polyposis coli gene product (APC) (Groden et al., 1991; Nishisho et al., 1991). Neurofibromin is most abundant in neurons (Daston et al., 1992; Golubic et al., 1992). Neurofibromin can interact with microtubules (Bollag et al., 1993; Gregory et al., 1993) and associates with lymphocyte plasma membranes (Boyer et al., 1994) and neuronal smooth endoplasmic reticulum (Nordlund et al., 1993). Neurofibromin is a GTPase-activating protein (GAP) for ras (McCormick, 1995), which is notable because GTP $\gamma \mathrm{S}$ inhibits fast axonal transport (Bloom et al., 1993).

APC is present in neurons (Horii et al., 1993; Bhat et al., 1994; Matsumine et al., 1996; Morrison et al., 1997), colocalizes with microtubules when it is overexpressed in cultured cells (Munemitsu et al., 1994; Smith et al., 1994), and promotes microtubule assembly and bundling in vitro (Munemitsu et al., 1994). Endogenous APC is localized to microtubule ends near membrane surfaces (Nathke et al., 1996) and to growth cones (Morrison et al., 1997). 
APC is implicated in cell signaling via binding to a variety of polypeptides (Moon and Miller, 1997). APC binds $\beta$-catenin (Rubinfeld et al., 1993, 1995; Su et al., 1993a; Hulsken et al., 1994) and Drosophila disks large (DLG) (Matsumine et al., 1996), a member of the PDZ protein family required for normal subsynaptic membrane structure (Garner and Kindler, 1996). APC interacts with EB-1 (Su et al., 1995), a homolog of which is required in yeast for microtubule integrity and the maintenance of cell form (Beinhauer et al., 1997). APC also binds specific kinases. Glycogen synthase kinase $3 \beta$ phosphorylates APC and binds an APC/ $\beta$-catenin complex (Rubinfeld et al., 1996; Yost et al., 1996). Cyclin-dependent kinases (CDKs) also interact with APC. CDK-p34 interacts with APC during M phase of the cell cycle (Trzepacz et al., 1997), implying an intersection between APC and CDK5 pathways. Both the $\beta$-catenin-binding domain and the C-terminal tubulin and DLG-binding domains of APC contain multiple putative phosphorylation sites (Groden et al., 1991; Nishisho et al., 1991), at least some of which are phosphorylated in vivo (Bhattacharya and Boman, 1995; Rubinfeld et al., 1996). In particular, APC contains 11 (S/T)PX(R/K) CDK consensus phosphorylation motifs.

CDKs control the cell cycle via interaction with cyclins (Ducommun et al., 1991; Gould et al., 1991; Gu et al., 1992; Norbury and Nurse, 1992). The major cdc2-like kinase activity in brain extracts is CDK5 (Hellmich et al., 1992; Lew et al., 1994, 1995). Neuronal CDK5 is activated by proteins unrelated to cyclins, the neuron-specific p35 (Tsai et al., 1994) and the axonal p67 (Shetty et al., 1995).

We analyzed effects of NF1, APC, and a CDK inhibitor on organelle movement in isolated squid axoplasm. This plasma membrane-free model contains uniformly polarized microtubules that maintain vigorous bidirectional $\mathrm{MBO}$ transport, and it can be perfused with probes for analyzing microtubule-based MBO transport (Brady et al., 1982, 1985). Experimental precedent exists for the regulation of $\mathrm{MBO}$ transport by the localized action of a kinase in axoplasm (McGuinness et al., 1989). Our results suggest that cdc2-like kinases and their substrates modulate fast axonal transport.

\section{MATERIALS AND METHODS}

Axoplasm and video microscopy. Axoplasm was extruded from giant axons dissected from squid (Loligo pealei) supplied by the Marine Biological Laboratory (Woods Hole, MA). Extruded axoplasm segments, $1-2.5 \mathrm{~cm}$ in length, were mounted in specimen chambers fabricated from number 0 thickness coverslips. Preparations were observed by differential interference contrast microscopy, using a $100 \times$ magnification, $1.3 \mathrm{nu}-$ merical aperture planapochromatic objective on a Zeiss Axiomat (Carl Zeiss, Thornwood, NY) interfaced with a Hamamatsu C1966 AVEC or Argus 20 image processor. Preparations of axoplasm were perfused with $\mathrm{X} / 2$ buffer [composed of (in mM) 175 potassium aspartate, 65 taurine, 35 betaine, 25 glycine, $10 \mathrm{HEPES}, 6.5 \mathrm{MgCl}_{2}, 5 \mathrm{EGTA}, 1.5 \mathrm{CaCl}_{2}$, and 0.5 glucose, $\mathrm{pH} 7.2$, supplemented with 1 ATP] containing specified amounts of recombinant proteins or inhibitors (Brady et al., 1990; Stenoien and Brady, 1997). Typically, $20 \mu$ l of perfusate was added to the chamber per $1 \mathrm{~cm}$ segment of axoplasm (approximate volume of $5 \mu \mathrm{l}$ (Brady et al., 1985). The concentrations of experimental probes that have been cited represented those in the buffer before perfusion into axoplasm, giving a final concentration that was $80 \%$ of starting value because of dilution by the axoplasm. After perfusion, velocity measurements of anterograde and retrograde transport were made for 35-55 min. Postperfusion measurements also were made for organelles traveling along microtubules of unknown polarity isolated at the axoplasm periphery. Velocity measurements were made in real time from the video monitor with a Hamamatsu C2117 video manipulator. Data were plotted and curves were fit by using Deltagraph software (DeltaPoint, Monterrey, CA). Statistical significance was evaluated with a pooled $t$ test of $\mu_{1}-\mu_{2}$, using DataDesk 5.0 (Data Description, Ithaca, NY).
Adenomatous polyposis coli $(A P C)$. APC proteins tagged with a six amino acid Glu-Glu epitope tag were expressed in baculovirus and purified to near-homogeneity [see Coomassie blue-stained preparations in Munemitsu et al. (1994)] from infected Sf9 cells by affinity chromatography, using an anti-Glu-Glu cross-linked protein G-Sepharose column. Proteins were eluted in (in mM) 20 Tris, pH 8.2, $100 \mathrm{NaCl}$, and 1 dithiothreitol plus $100 \mu \mathrm{M}$ peptide (EYMPTD), with protease inhibitors $(10 \mu \mathrm{g} / \mathrm{ml}$ each of pepstatin A, leupeptin, and Pefablock and $1 \mathrm{~mm}$ aprotinin). Recombinant proteins that were used were APC2 (amino acids 1034-2130), APC3 (aa 2130-2844), and APC4 (aa 1034-2844), as described previously (Munemitsu et al., 1994). All APC recombinant proteins were a generous gift of Dr. Paul Polakis of Onyx Pharmaceuticals (Richmond, CA). APC recombinant fragments were diluted just before use to give indicated concentrations in buffer $\mathrm{X} / 2$. Buffer controls used volumes of APC elution buffer in buffer $\mathrm{X} / 2$ equivalent to the highest concentrations of APC fragments used. Polyclonal antibodies raised in rabbits against purified APC2 and APC3 proteins (Rubinfeld et al., 1993) were a generous gift of Dr. Polakis.

Neurofibromin (NF1). Full-length neurofibromin (2818 amino acids) also was expressed by using the pAcC14 baculovirus vector and was purified from extracts of infected Sf9 cells to near-homogeneity, as described previously (Bollag et al., 1993). Briefly, cells expressing a full-length neurofibromin construct with an epitope tag added to the $\mathrm{N}$ terminus were lysed, and neurofibromin was purified by immunoaffinity chromatography, using a monoclonal antibody against the tag. Bound neurofibromin was eluted in NF1 elution buffer [half-strength PBS containing $0.1 \% n$-octylglucoside, $2 \mathrm{~mm} \beta$-mercaptoethanol, $25 \mu \mathrm{g} / \mathrm{ml}$ of elution peptide (EYMPME), and $40 \%$ glycerol] brought to a final concentration of $0.5 \mathrm{mg} / \mathrm{ml}$. Neurofibromin was diluted just before use to give the indicated concentrations in buffer $\mathrm{X} / 2$. Buffer controls used equivalent volumes of the NF1 elution buffer in buffer $\mathrm{X} / 2$.

Inhibitors. Olomoucine and iso-olomoucine were obtained from LC Labs (Woburn, MA) and stored in DMSO at $20 \mathrm{~mm}$. Histone H1 was obtained from Life Technologies (Gaithersburg, MD) and dissolved in water before use at the stated concentrations. The KSPXK peptide inhibitor was a generous gift of Dr. Harish Pant (National Institutes of Health, Bethesda, MD). KSPXK was taken up in buffer X/2 at the stated concentrations.

\section{RESULTS}

The effects of NF1 and APC on the transport of MBOs were determined by perfusing recombinant polypeptide into isolated squid axoplasm. As in previous video microscopic studies of axonal transport in isolated axoplasm (Brady et al., 1985, 1990), three classes of organelle velocity measurements were made. In the axoplasm interior, where microtubules are aligned parallel to the long axis of the axon with the plus ends distal, velocities were determined for anterograde and retrograde fast axonal transport. These two categories of transport are distinguished both by direction of movement relative to microtubule polarity and types of membrane-bound organelles being moved. Average rates correlate with the physical size of organelles, because small organelles move almost continuously whereas larger organelles pause more frequently, resulting in a lower average velocity (Allen et al., 1982; Martz et al., 1984; Brady et al., 1985). Changes in velocity under these conditions reflect changes in the efficiency of transport.

The third class of measurements was of MBOs moving along individual microtubules at the periphery of the axoplasm. Because isolated microtubules form by separating from the axoplasm after buffer perfusion, their polarity cannot be determined unambiguously. Movement of individual MBOs along peripheral microtubules is evaluated more readily than in the intact axoplasm, because more favorable optic conditions permit extended analysis of their movements. This results from two circumstances. First, microtubules in the interior are surrounded by other components of the axonal cytoskeleton, which form a dense meshwork of filaments and other structures that can impede the movement of organelles (Morris and Lasek, 1982). The density of 


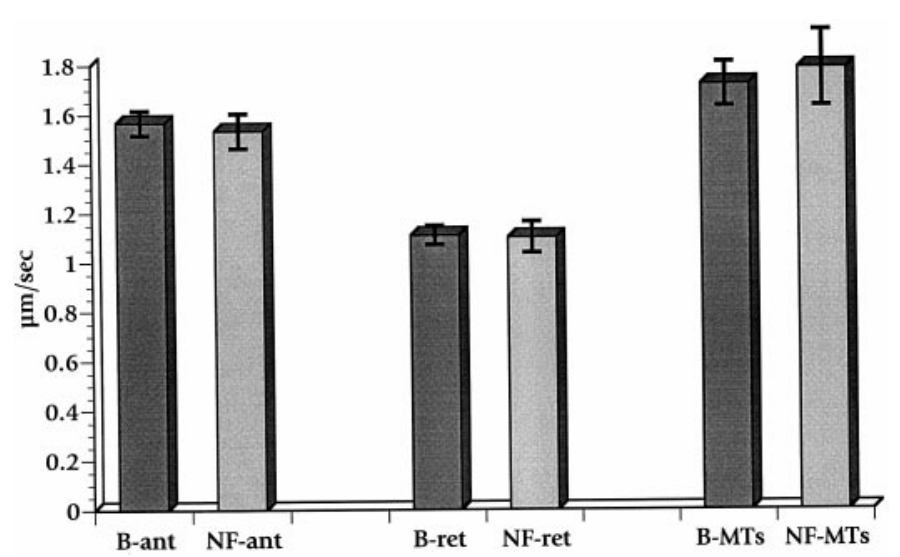

Figure 1. Lack of effect of neurofibromin on fast axonal transport in isolated axoplasm. Organelle velocities were measured after the perfusion of axoplasm with buffer $\mathrm{X} / 2$ supplemented with the neurofibromin buffer $(B)$ or with $0.5 \mu \mathrm{M}$ neurofibromin $(N F)$. Velocity measurements taken between 25 and $45 \mathrm{~min}$ were combined, and the SEM was calculated. No significant differences were detected between buffer and NF values for either anterograde (ant) or retrograde (ret) fast axonal transport. The movement of organelles along isolated microtubules (MTs) also was not affected by treatment with neurofibromin.

structures in this region limits effective resolution of individual organelles (Brady et al., 1985). Second, microtubules in the interior move in and out of the $200 \mathrm{~nm}$ plane of focus, whereas the same microtubule often can be followed for $10-20 \mu \mathrm{m}$ at the periphery. The three classes of measurement allowed us to distinguish between effects on microtubules or motor proteins and indirect actions involving other cytoplasmic constituents (McGuinness et al., 1989).

We first evaluated the effects of NF1, which combines a GTPase activation domain with a microtubule-binding domain (Gregory et al., 1993; McCormick, 1995). When full-length NF1 protein (2818 amino acids) purified from baculovirus extracts was perfused into axoplasm at a concentration of $\sim 0.5 \mu \mathrm{M}$, organelle movement remained robust for at least $40 \mathrm{~min}$ (Fig. 1). Fast transport was not significantly different from that seen with buffer controls lacking recombinant protein. Similar fractions of purified human NF1 expressed in baculovirus interact with both microtubules and ras (Bollag et al., 1993), and human NF1 fragments expressed in yeast complement mutations in yeast GAP (Ballester et al., 1990). The inability to detect the effects of NF1 on fast axonal transport suggests that the small GTPases affecting fast axonal transport (Bloom et al., 1993) are not in vivo targets of NF1 GAP activity.

Recombinant APC fragments did affect axonal transport. APC4, an APC fragment lacking the N-terminal heptad repeat domain but containing both $\beta$-catenin-binding and microtubulebinding domains (Fig. 2), had a striking effect on both the average velocity and the amount of material in fast anterograde axonal transport. Scatter plots of combined data from five axoplasm preparations with buffer alone (Fig. $3 A$ ) and from five axoplasms treated with APC4 $(100 \mu \mathrm{g} ; \sim 0.5 \mu \mathrm{M})$ (Fig. $3 B)$ show that APC4 reduced the movement of $\mathrm{MBOs}$ in the anterograde direction preferentially. The rate and amount of organelle movement in the retrograde direction was the same in buffer-treated or APC4treated axoplasm preparations. The effects of APC4 on anterograde transport direction were dose-dependent over APC4 concentrations of $0.01-0.5 \mu \mathrm{M}$ (Fig. 4). The differences from buffer control were significant at $p<0.0001$ for 0.5 and $0.1 \mu \mathrm{M}$, at $p<$
0.001 for $0.05 \mu \mathrm{M}$, and at $p<0.05$ for $0.01 \mu \mathrm{M}$ APC4. In addition to the reduction in mean anterograde velocity, APC4 treatments led to a demonstrable and repeatable (video records available on request) qualitative reduction in the number of MBOs undergoing anterograde transport. This effect could not be quantitated precisely, because most individual MBOs have dimensions below the diffraction limit of light microscopy (Brady et al., 1985). Repeated freeze-thaw cycles of APC4 preparations abolished its ability to reduce transport in this assay.

Curiously, the mean velocity of MBOs moving along individual microtubules was not significantly different from buffer controls at the highest APC4 concentration that was analyzed (see Fig. 3B), but mean velocities were reduced at lower concentrations (Fig. $4 C$ ). However, MBOs moving along peripheral microtubules were rarely seen at the highest concentration of APC4 that was examined $(0.5 \mu \mathrm{M})$. At lower concentrations of APC4 (0.05-0.1 $\mu \mathrm{M})$ the MBOs moving along peripheral microtubules were more abundant, but the majority of those paused frequently and moved inefficiently, giving a mean velocity significantly lower than buffer controls (Fig. 4C). The persistence of a few MBOs moving at control rates on isolated microtubules in $0.5 \mu \mathrm{M}$ APC4 suggested that $\mathrm{MBO}$ populations that are affected differentially by APC4 may exist. At $0.5 \mu \mathrm{M}$ APC4, virtually all APC4-sensitive transport may have ceased, leaving only those MBOS for which the movements were unaffected by APC4. At lower concentrations many APC4-sensitive MBOs continued to move with low efficiency, thereby reducing the mean velocity.

Because APC4 contains several distinct biological activities, the identification of specific domains responsible for the inhibition of fast anterograde transport was important. The effects of two smaller, nonoverlapping APC fragments derived from APC4 were analyzed to characterize APC inhibition of anterograde transport further (see Fig. 2). APC2 and APC3 were each perfused into isolated axoplasm at molar concentrations comparable to those used for APC4. Both APC2 (containing the $\beta$-cateninbinding domain) and APC3 (containing the microtubule-binding domain) inhibited $\mathrm{MBO}$ movement in axoplasm. Figure $3 C$ shows a time course of APC2 at $0.5 \mu \mathrm{M}$. Figure 4 (right) shows data from measurements between 25 and 40 min after perfusion. APC2 at $0.5 \mu \mathrm{M}$ slowed both anterograde and retrograde $\mathrm{MBO}$ velocity $(p<0.0001)$, whereas $0.15 \mu \mathrm{M}$ APC2 had no effect on motility. APC3 similarly slowed anterograde transport $(p<0.0001)$, retrograde transport $(p<0.01)$, and $\mathrm{MBO}$ movement on fibrils $(p<0.01)$ significantly (see Figs. 3D, 4). APC3 was more potent than APC2 and affected transport even at the lowest concentrations that were tested $(0.05 \mu \mathrm{M})$, comparable to APC4. That APC4 specifically interfered with anterograde transport, whereas both APC2 and APC3 reduced both anterograde and retrograde transport, indicated that one or more of the protein motifs found in APC4 confer specificity.

Several possible mechanisms were considered to explain APC modulation of fast axonal transport. To determine whether APC treatment disrupted axoplasm, we fixed and processed for electron microscopy those axoplasms that had been treated with APC3 or buffer X for 20 min. Longitudinal and cross sections were examined in seven regions from each axon. No apparent difference in organization was noted between APC-treated and control axoplasms. Similarly, an examination of axoplasms by immunofluorescence that used antibodies specific for tubulin or APC4 failed to show any consistent changes in axoplasmic organization after perfusion with APC. As predicted from microtubule-binding studies 
Figure 2. Diagram of the APC protein and recombinant fragments used in this study, with some of the major motifs designated. Of note are three prolinedirected serine/threonine kinase consensus phosphorylation sites $(\mathrm{S} / \mathrm{T}) \mathrm{PX}(\mathrm{R} / \mathrm{K})$ within $\mathrm{APC} 2$, designated by filled triangles, and eight proline-directed serine/threonine kinase consensus phosphorylation sites in the APC 3 fragment. These APC fragments and their biochemical characterization have been described previously (Munemitsu et al., 1994).

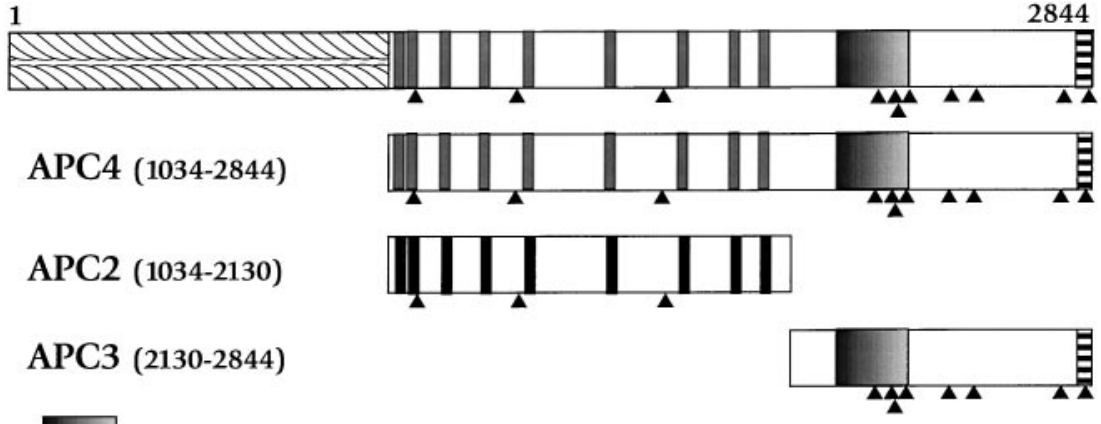

Basic domain (putative microtubule binding site)

20 amino acid repeat (implicated in $\beta$-catenin and GSK binding)

Consensus cdc kinase phosphorylation motif

Discs Large binding

Dimerization domain (contains heptad and armadillo repeats)
Figure 3. Time course of the effects of buffer $(A), \operatorname{APC} 4(B), \operatorname{APC} 2(C)$, and APC3 $(D)$ on fast anterograde and retrograde axonal transport. APC4 $(0.5 \mu \mathrm{M})$ inhibited fast anterograde, but not retrograde, transport. In contrast, APC2 $(0.5 \mu \mathrm{M})$ and APC3 $(0.05 \mu \mathrm{M})$ inhibited both directions of fast axonal transport. Individual velocity measurements are shown as points. Black squares are anterograde velocities, gray circles are retrograde velocities, and open triangles denote velocity on isolated microtubules. Curves were fit for anterograde movement (black lines) and retrograde movement (gray lines) by using an exponential curve fit. No curves are shown for movement on microtubules, because measurements were more variable over this interval and did not exhibit a consistent trend.
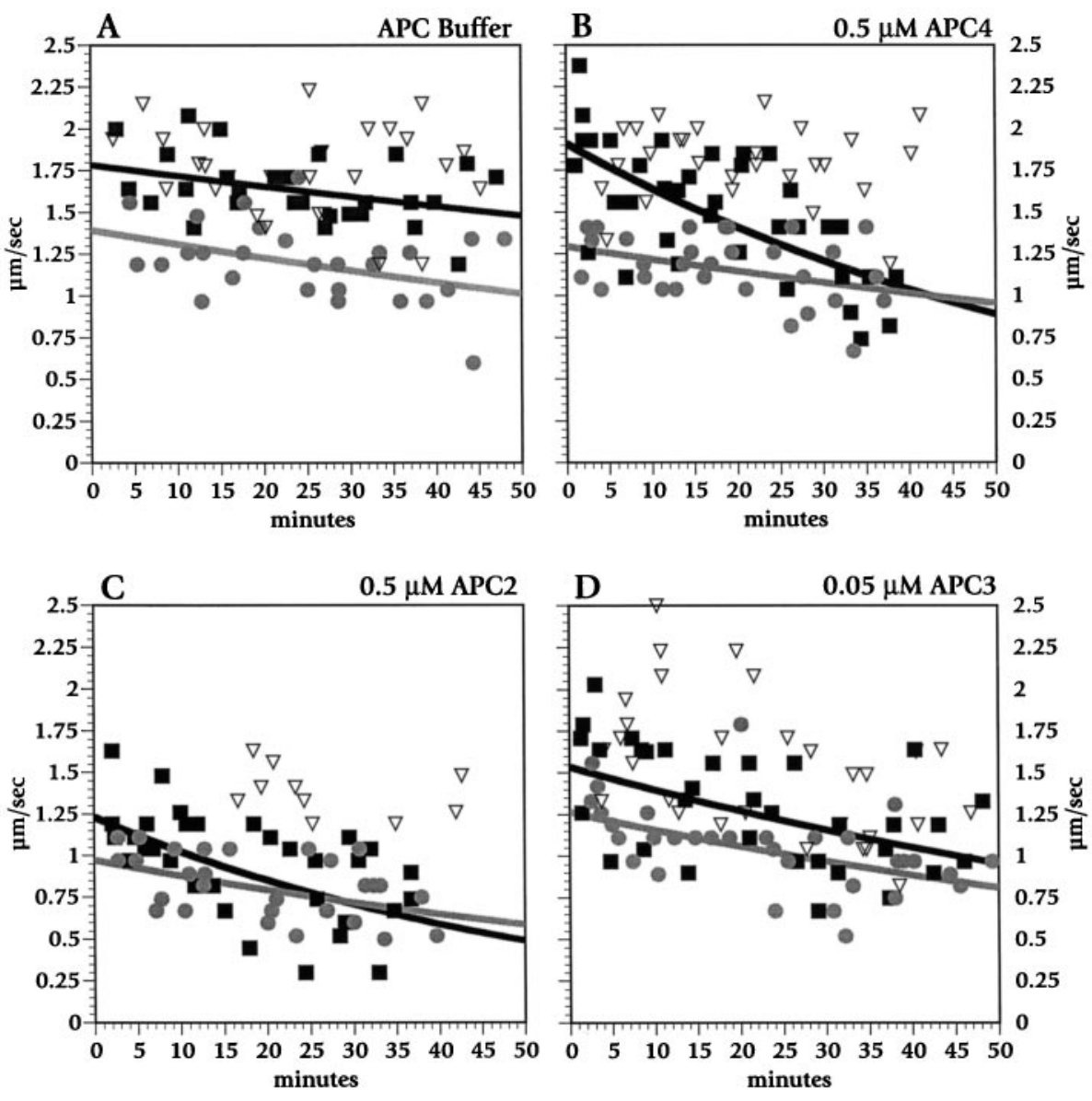

Anterograde

- Retrograde

$\nabla$ MTs
(Munemitsu et al., 1994; Smith et al., 1994), APC4 immunoreactivity appeared to be associated with microtubule-rich domains of axoplasm in double-label experiments that used tubulin and APC antibodies (data not shown). Similarly, video- enhanced contrast differential interference contrast microscopy failed to reveal obvious differences in organization or integrity of isolated axoplasms treated with any of the APC recombinant proteins. 
A
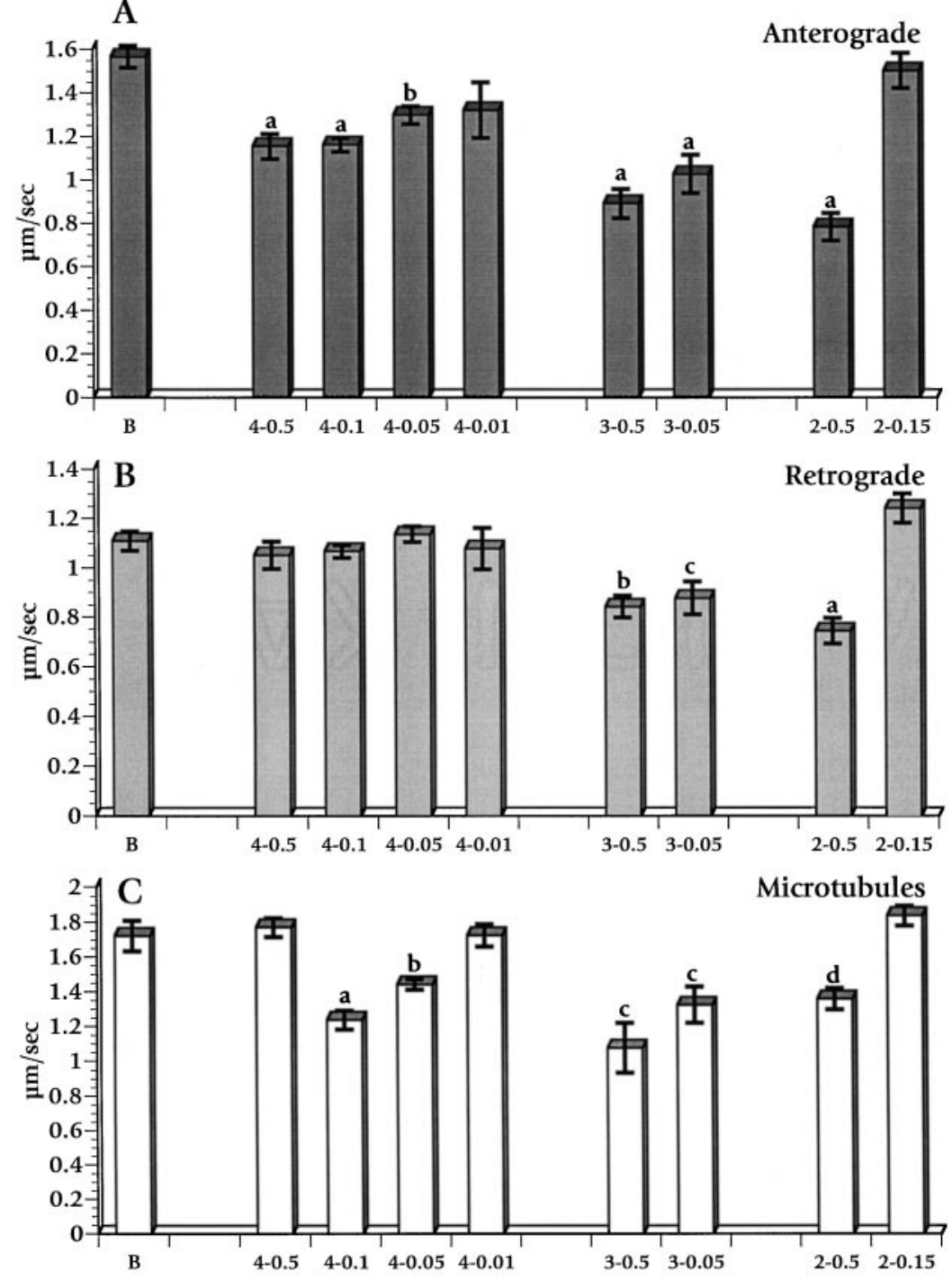

Figure 4. Dose-response histograms showing the effect of APC fragments on fast anterograde $(A)$ and retrograde $(B)$ axonal transport and on isolated microtubules $(C)$. $B$ designates buffer control; the identity is listed, and the micromolar concentration of each APC protein is given after a dash (e.g., $4-0.5$ is APC4 at $0.5 \mu \mathrm{M})$. Values are means of measurements taken 25-40 min after perfusion for each condition. Error bars indicate SEM. Statistical significance for differences from buffer controls was evaluated by a pooled $t$ test of $\mu_{1}-\mu_{2}$. Error bars labeled $a$ indicate $p<0.0001 ; b$ reflects $p<$ $0.001 ; c$ reflects $p<0.01 ; d$ reflects $p<0.02$.
The observation that both APC2 and APC3 slowed anterograde and retrograde axonal transport suggested that a shared feature might be responsible. Both APC2 and APC3 contain consensus motifs $(\mathrm{S} / \mathrm{T}) \mathrm{PX}(\mathrm{K} / \mathrm{R})$ for the CDK family of prolinedirected kinases (Trzepacz et al., 1997), raising the possibility that APC fragments might act as competitive inhibitors for one or more endogenous proline-directed serine/threonine kinases. Two alternative proline-directed serine/threonine kinase substrates were perfused into axoplasm to test this possibility. The first was a synthetic $36 \mathrm{mer}$ peptide derived from rat neurofilament $\mathrm{H}$ multiple KSP repeats (a gift from Dr. Harish Pant) with the sequence KSPVKEEAKSPAEAKSPAEAKSPAEAKSPAEVKSPA. This peptide, called KSPXK for the sake of brevity, previously was used to purify a cdc2-like kinase from rat spinal cord (Shetty et al., 1993). Perfusion of axoplasm with KSPXK over a concentration range in which KSPXK was found to be active as a substrate for cdc2-like kinases (0.1-1.0 mM) inhibited both anterograde and retrograde axonal transport (Fig. 5A,B). Histone H1, another polypeptide with multiple proline-directed kinase consensus phosphorylation sites, similarly inhibited both anterograde and retrograde axonal transport in axoplasm at concentrations between 0.05 and $5 \mu \mathrm{M}$ (Fig. $5 A, B$ ). Because four biochemically dissimilar protein substrates for cyclin-dependent kinases (APC2, APC3, KSPXK, and histone $\mathrm{H} 1$ ) reduced both anterograde and retrograde axonal transport in axoplasm, a common mode of action was likely. All of these polypeptides might act as competitors of substrates of one or more proline-directed kinases. This in turn strongly suggests that the activity of such kinases modulates normal axonal transport.

To minimize the number of candidate proline-directed serine/ threonine kinases and evaluate the potential of cyclin-dependent kinase family members to modulate fast axonal transport, we examined the actions of a pharmacological agent with considerable selectivity among kinase classes. Olomoucine is a purine derivative that acts as a competitive inhibitor of ATP binding to enzymes and is highly specific for cdc2/CDK2 and CDK5 kinases. Olomoucine inhibits cdc-like kinases at micromolar concentrations, whereas other classes of kinase require substantially higher concentrations (Vesely et al., 1994; Meijer et al., 1997). At $50 \mu \mathrm{M}$, a concentration at which olomoucine inhibits erk-1 and MAP kinases as well as cdc2-like kinases, olomoucine slowed transport in anterograde and retrograde directions as well as movement on isolated microtubules (Figs. 5C,D, 6A). The extent of inhibition for $50 \mu \mathrm{M}$ olomoucine was comparable to that seen with APC2, APC3, KSPXK, and histone H1. Equivalent concentrations of 


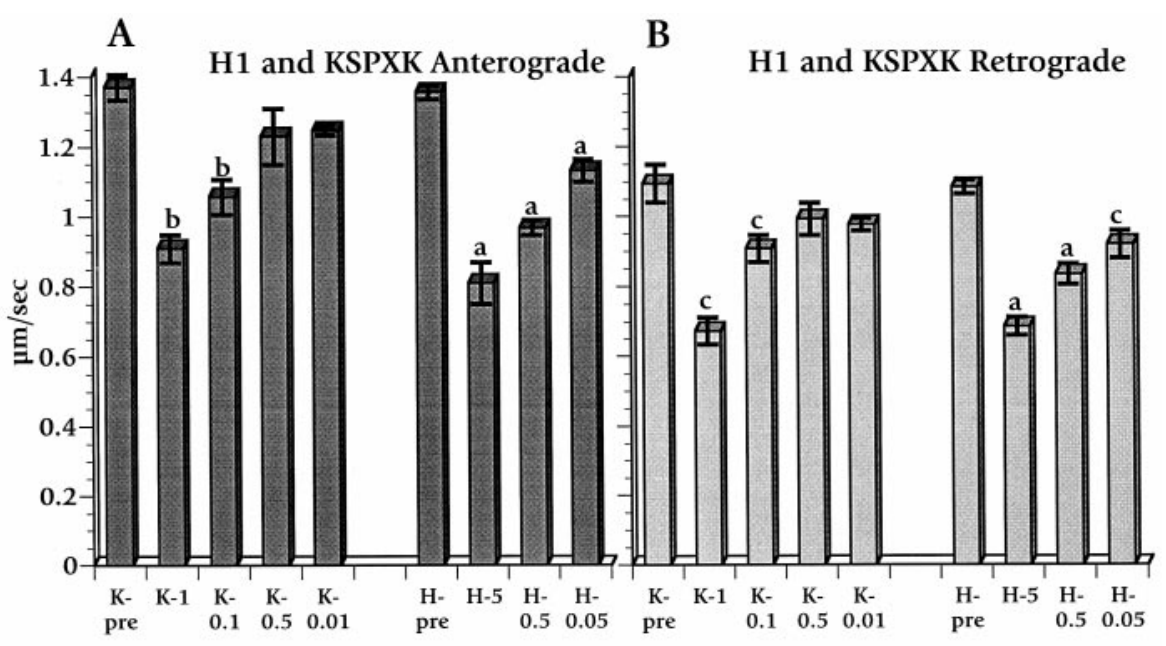

Figure 5. Effects of perfusing histone H1, KSPXK (a synthetic peptide substrate for prolinedirected serine/threonine kinases), and olomoucine on fast anterograde and retrograde axonal transport. Histone $\mathrm{H} 1 \quad(H-n ; n=$ concentration in $\mu \mathrm{M})$ and $\mathrm{KSPXK}(K-n ; n=\mathrm{con}-$ centration in $\mathrm{mM}$ ) decreased both anterograde $(A)$ and retrograde $(B)$ transport at all effective concentrations. In contrast, olomoucine affects anterograde $(C)$ and retrograde $(D)$ differentially. Olomoucine at $5 \mu \mathrm{M}(O-5)$ and APC4 at $0.1 \mu \mathrm{M}$ (A4) individually affect only anterograde transport, whereas $50 \mu \mathrm{M}$ olomoucine $(O-50)$ and a combination of $0.1 \mu \mathrm{M}$ APC4 with $5 \mu \mathrm{M}$ olomoucine $(A 4 / O)$ slow both directions. Isoolomoucine $(I)$ is an inactive isomer of olomoucine. Values are the means of measurements between 25 and $40 \mathrm{~min}$ after the perfusion of designated factors into axoplasm. Statistical analyses and error measurements are the same as for Figure 4. Premeasurements (O-pre) represent organelle velocities before perfusion with the designated reagent.

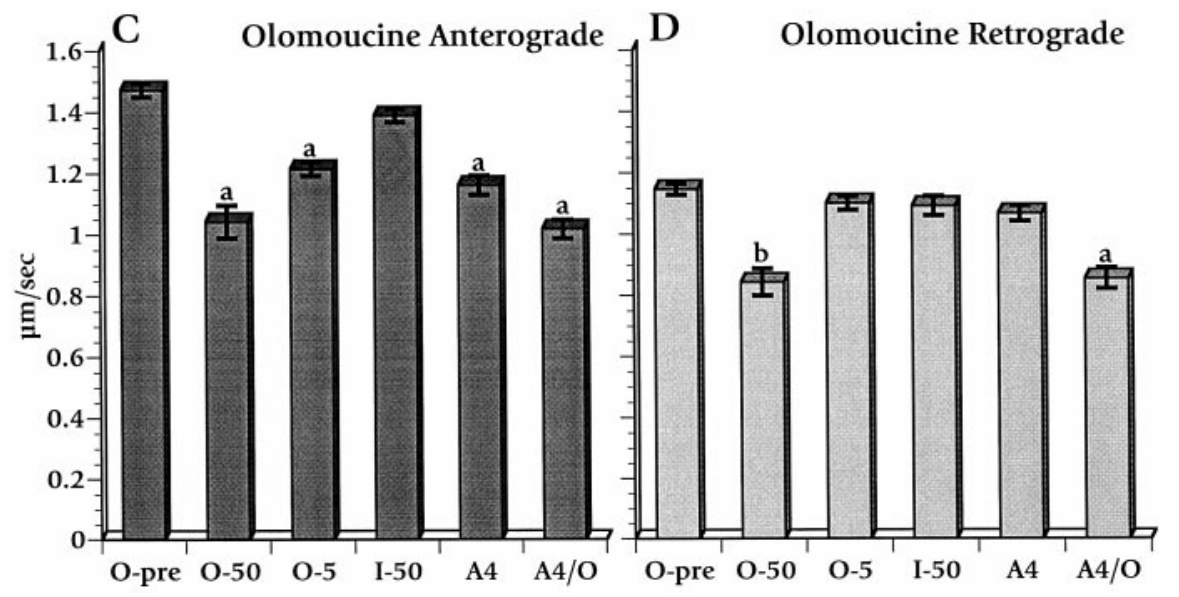

iso-olomoucine, an inactive analog with no effect on kinase activity, had no effect on fast axonal transport (Figs. 5C,D, 6B).

Remarkably, olomoucine at $5 \mu \mathrm{M}$, a concentration at which it specifically inhibits cdc2-like (CDK2 and CDK5) kinases, affected only anterograde $\mathrm{MBO}$ transport (Figs. $5 C, D, 6 C$ ). Effects of 5 $\mu \mathrm{M}$ olomoucine on fast anterograde transport were comparable to those seen after perfusion with APC4 at $0.1 \mu \mathrm{M}$ (Fig. 5C,D). Perfusion with a combination of $5 \mu \mathrm{M}$ olomoucine and $0.1 \mu \mathrm{M}$ APC4, each of which individually affected only anterograde transport, inhibited both anterograde and retrograde transport to an extent comparable to $50 \mu \mathrm{M}$ olomoucine (Figs. 5C,D, 6D). This synergy indicates that olomoucine and APC4 effects are additive, suggesting that they act along the same pathway.

\section{DISCUSSION}

Our data suggest that fast axonal transport is regulated by axonal, olomoucine-sensitive, proline-directed kinases. Olomoucine did not halt but, rather, diminished vesicle transport along microtubules, indicating that olomoucine-sensitive kinases play a modulatory role in axonal transport. A likely candidate for a prolinedirected kinase affecting anterograde fast transport is neuronal CDK5, which is known to be present in squid axons (Takahashi et al., 1995) and vertebrate neurons (Hellmich et al., 1992; Lew et al., 1994). Retrograde axonal transport appears to be modulated by non-CDK proline-directed kinases. Several lines of evidence support our conclusions.

First, the CDK inhibitor olomoucine, at 5 ( $\mu \mathrm{M}$, significantly diminishes anterograde movement of vesicles in squid axoplasm. At $5 \mu \mathrm{M}$, olomoucine is highly specific for $\operatorname{cdc} 2, \mathrm{CDK} 2$, and CDK5. At $5 \mu \mathrm{M}$, olomoucine does not inhibit cAMP-dependent or cGMP-dependent kinases, numerous protein kinase $\mathrm{C}$ isoforms, casein kinase, myosin light chain kinase, or various tyrosine kinases (Vesely et al., 1994; Meijer et al., 1997). Importantly, even proline-directed kinases, including glycogen synthase kinase 3 and MAP kinases, are not inhibited by $5 \mu \mathrm{M}$ olomoucine (Vesely et al., 1994; Meijer et al., 1997). K252a, an inhibitor of protein kinases A, C, and G, also does not affect organelle velocity in squid axoplasm (Bloom et al., 1993). Consistent with a role for CDK-like kinases in the modulation of anterograde $\mathrm{MBO}$ movement, CDKs have been implicated in the regulation of microtubule function. p34 ${ }^{\mathrm{cdc} 2} /$ cyclin $\mathrm{B}$ complex associates with microtubules in interphase cells (Ookata et al., 1993), and squid CDK5 is found in a protein complex that includes microtubule proteins (Shetty et al., 1993; Takahashi et al., 1995). We anticipate that $\mathrm{CDK}$ activity is regulated by the presence of CDK inhibitors and CDK substrates within axons and that the sum of these variables influences the extent of vesicle trafficking in specific axonal regions (Fig. 7). The activity of CDKs may vary during development or during nerve regeneration, affecting vesicle transport. Specific CDK substrates relevant to the modulation of axonal transport remain to be defined. Below, we evaluate the possibility that APC is a CDK substrate with the potential to modulate CDK function, and thus vesicle motility, in situ.

APC4, which contains $11 \mathrm{CDK}$ phosphorylation sites, mim- 

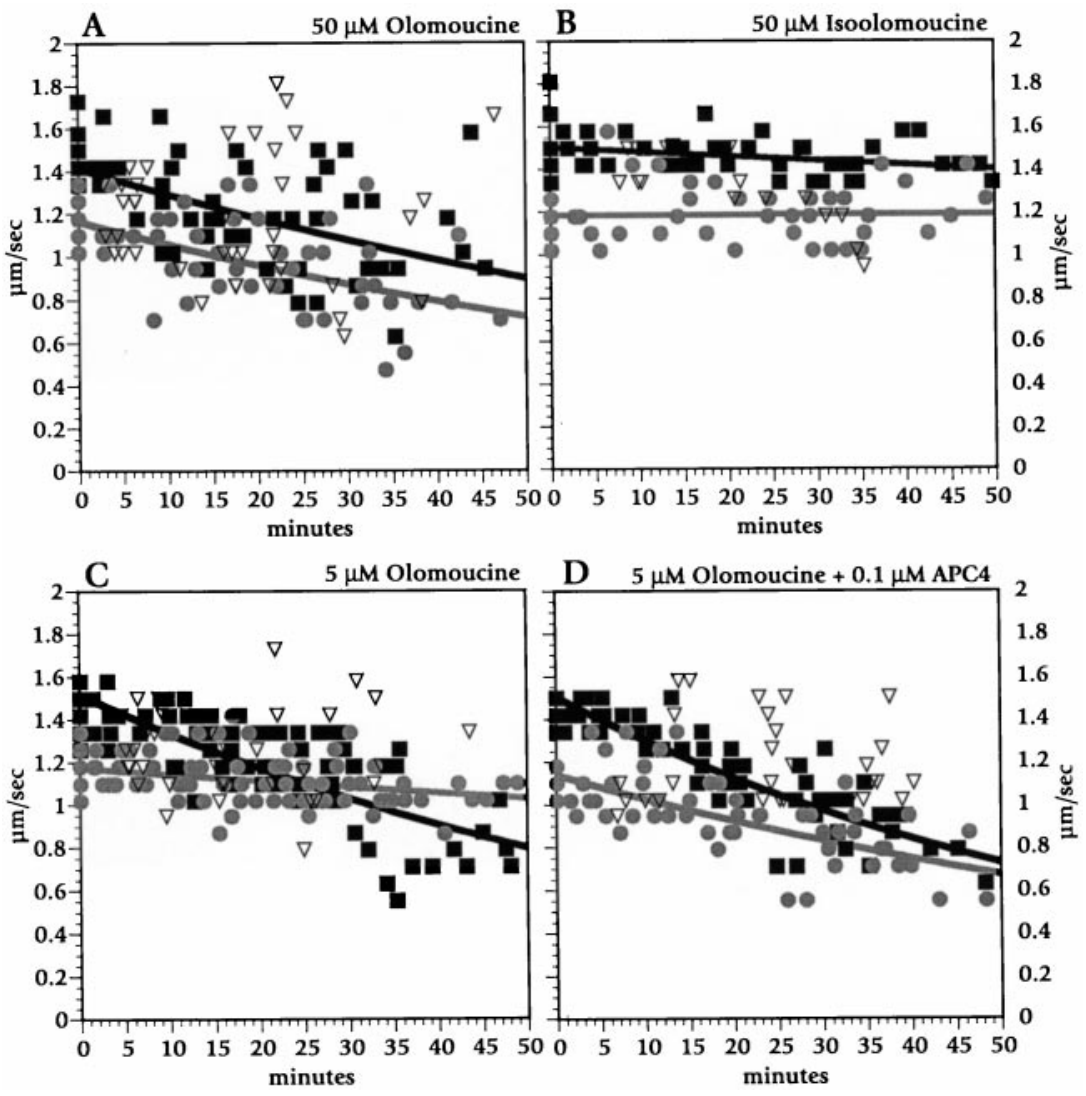

Figure 6. Time course for the effects of olomoucine and its inactive analog iso-olomoucine on fast anterograde and retrograde axonal transport. Olomoucine $(50 \mu \mathrm{M} ; A)$ reduced anterograde (black squares and black line) and retrograde (gray circles and gray line) transport to a similar extent. Iso-olomoucine at $50 \mu \mathrm{M}(B)$ had no detectable effect on transport. At $5 \mu \mathrm{M}(C)$, olomoucine inhibited only anterograde movement. Co-perfusion of $0.1 \mu \mathrm{M}$ APC4 and $5 \mu \mathrm{M}$ olomoucine $(D)$ inhibited both anterograde and retrograde axonal transport.

Figure 7. Model depicting possible actions of APC4 and CDKs in the modulation of anterograde axoplasmic transport. Our data suggest that CDKs on or near axonal microtubules maintain the normal rate of transport of anterograde-moving organelles along microtubules. In this model one function of APC is to act as a competitive inhibitor of phosphorylation by CDKs, effectively shielding microdomains from the activity of bound kinases. Binding APC4 to a microtubule (bottom microtubule in $A$ and enlargement in $B$ ) sequesters the microtubule-associated CDK (and/or other kinase) activity. This inhibits anterograde transport in that microtubule domain, whereas fast transport continues unabated in APC-poor regions of the same axon (top two microtubules in $A)$; CDKs involved in the phosphorylation of alternative targets (e.g., neurofilaments) are unaffected. This mechanism may represent part of a targeting process, because organelles would be off-loaded from microtubules in APC-rich regions of axons. Such an activity may represent a general mechanism by which cells can tailor their response to signal transduction pathways by protecting subcellular

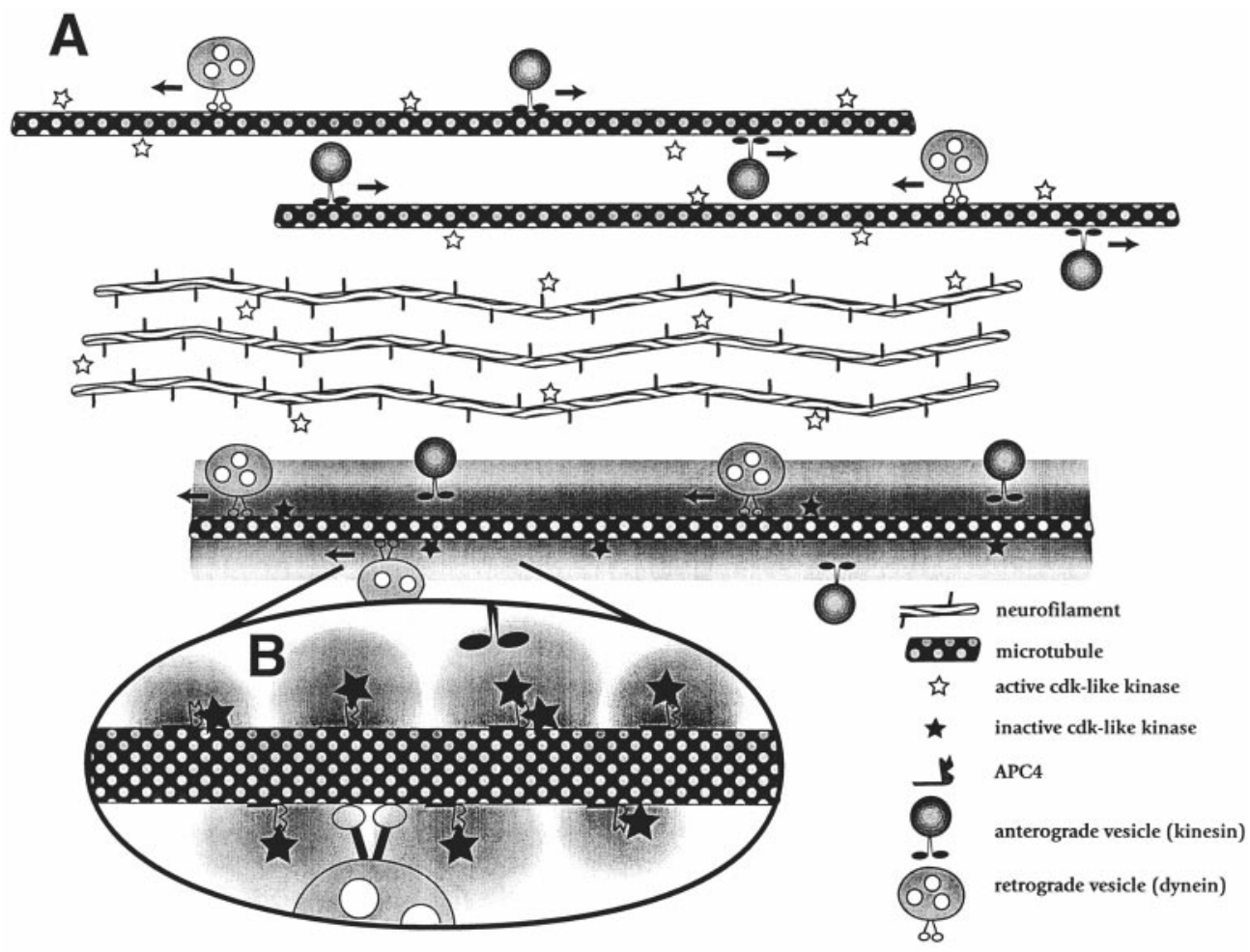
domains.

icked the action of $5 \mu \mathrm{M}$ olomoucine on anterograde transport, consistent with inhibition of axoplasmic kinases being the mechanism by which APC4 diminishes fast axonal transport. APC4 diminished anterograde transport (at all concentrations tested), with no effect on retrograde transport. APC is the first protein demonstrated to inhibit one direction of fast axonal transport preferentially. Most polypeptides, including NF1 (this study), modified myosin fragments (Brady et al., 1985), antibodies 
(Johnston et al., 1987; Brady et al., 1990; Stenoien and Brady, 1997), and calmodulin/calmodulin kinase II (McGuinness et al., 1989), have little or no effect on axonal transport. Other proteins affect both anterograde and retrograde transport; these include antibodies against kinesin (Brady et al., 1990; Stenoien and Brady, 1997) or tubulin (Johnston et al., 1987), dephosphorylated synapsin (McGuinness et al., 1989), and gelsolin with micromolar $\mathrm{Ca}^{2+}$ (Brady et al., 1984). Similarly, various nonprotein effectors, including GTP $\gamma \mathrm{S}$ (Bloom et al., 1993), $N$-ethylmaleimide (Pfister et al., 1989), and AMP-PNP, a nonhydrolyzable analog of ATP (Brady et al., 1985; Lasek and Brady, 1985), inhibit both anterograde and retrograde transport. As a result, understanding mechanisms by which APC4 affects anterograde transport is likely to illuminate the regulation of anterograde transport, regardless of the normal physiological functions for neuronal APC.

Is APC a plausible candidate to play a role in modulating axonal transport in vivo? We suggest that it is. First, recombinant APC inhibits fast anterograde transport at relatively low concentrations $(10-50 \mathrm{nM})$, indicating that its action is specific and has high affinity. By comparison, kinesin is in squid axoplasm at $\sim 500$ nM (Brady et al., 1990), whereas tubulin in axoplasm is present at $4 \mu \mathrm{M}$ (Morris and Lasek, 1984). Second, $>95 \%$ of APC mutations leading to familial adenomatous polyposis are missing all or part of the microtubule-binding domain (Polakis, 1995; Beroud and Soussi, 1996). This suggests that APC must bind microtubules to function normally. Third, although full-length APC expressed in baculovirus was not available at sufficiently high concentration to test for its effects on axonal transport, the N-terminal APC domain missing from APC proteins tested in this study may not be critical for all APC functions. APC forms that are missing the N-terminal dimerization motif (Joslyn et al., 1993; Su et al., 1993b) are found in brain (Santoro and Groden, 1997; Pyles et al., 1998). Finally, some evidence suggests that the physiological functions of APC involve CDKs. Overexpression of APC in non-neuronal cells blocks cell cycle progression from G0/G1 to S phase (Baeg et al., 1995), the first transition requiring CDK activity during the cell cycle. APC becomes hyperphosphorylated during M phase of the cell cycle (Bhattacharya and Boman, 1995; Bhattacharjee et al., 1996; Trzepacz et al., 1997), the second peak of CDK activity. These findings are consistent with a negative modulation of cyclin-CDK complex activity by APC that can be overcome by phosphorylation of APC. Indeed, the effects of APC on the cell cycle parallel those seen with olomoucine treatment (Vesely et al., 1994).

Some less-definitive evidence suggests a link between APC and $\mathrm{CDK}$ in neurons. APC is upregulated during rat CNS development (Bhat et al., 1994) and differentiation of PC12 cells (Dobashi et al., 1996). PC12 differentiation is inhibited by constitutive overexpression of CDK2 (Dobashi et al., 1995). Olomoucine also inhibits PC12 differentiation (Park et al., 1996) (although the olomoucine levels that were used would affect kinases in addition to CDKs). These observations are consistent with the hypothesis that a functional connection exists between APC and cdc-like kinase activity in neuronal and non-neuronal cells.

We propose that the modulation of vesicle trafficking via local inhibition of CDK-like kinases may be a novel aspect of APC function. Anterograde transport is predicted to be low in regions where local APC concentrations are high and robust in cellular regions with low APC (see Fig. 7). For example, APC enriched at microtubule ends near the plasma membrane would allow delivery of vesicles for insertion into the plasma membrane. APC is enriched near the leading plasma membrane of actively migrating cells (Nathke et al., 1996) and in growth cones (Morrison et al., 1997), locations in which vesicles must leave microtubules. The idea that APC is involved in a pathway or pathways regulating vesicle-membrane interactions is consistent with the subcellular distribution of APC-binding partners $\beta$-catenin (Nathke et al., 1994, 1996; Miyashiro et al., 1995) and DLG (Lahey et al., 1994). For example, $\beta$-catenin is enriched in the microtubule and vesiclerich transport zones near the cell surface of frog embryos (Rowning et al., 1997), a localization that is thought to be regulated by interaction with APC (Miller and Moon, 1997).

Our data support a role for proline-directed kinases in modulating retrograde vesicle movement. Combining APC4 with $5 \mu \mathrm{M}$ olomoucine diminished anterograde and retrograde organelle movement, although each alone inhibited only anterograde transport. Presumably, the combination inhibits a broader range of kinases than either does alone. Consistent with this notion, olomoucine at $50 \mu \mathrm{M}$ diminished both anterograde and retrograde $\mathrm{MBO}$ movement. At this dose, olomoucine inhibited erk-1 ( $\mathrm{IC}_{50}$ $=25 \mu \mathrm{M})$, MAP kinases $\left(\mathrm{IC}_{50}=30 \mu \mathrm{M}\right)$, and glycogen synthase kinase (GSK) $\left(\mathrm{IC}_{50}=130 \mu \mathrm{M}\right)$ as well as CDKs (Vesely et al., 1994; Meijer et al., 1997). These or as yet unidentified kinases therefore are candidates to regulate retrograde organelle trafficking.

Our finding that APC2 and APC3, histone H1, and KSPXK inhibit fast anterograde and retrograde axonal transport supports the hypothesis that non-CDK proline-directed kinases modulate retrograde axonal transport. All of these polypeptides are substrates for multiple proline-directed kinases. APC2 and APC3 contain consensus phosphorylation sites for MAP kinases as well as for CDKs, and APC2 is a target for phosphorylation by GSK (Rubinfeld et al., 1996). Histone H1 is a substrate for many of these same kinases (Cicirelli et al., 1988; Boulikas, 1995), and KSPXK may be phosphorylated by proline-directed serine/threonine kinases not related to cdc2 (Takahashi et al., 1995). We suggest that all reduce fast anterograde and retrograde axonal transport by acting as competitive inhibitors of endogenous substrate phosphorylation. Because fragments derived from APC4 affected both anterograde and retrograde organelle movement, the specificity of APC4 for anterograde transport must result from the combined properties of APC2 and APC3. Linking these two domains could produce alterations in protein folding, protein-protein interactions, and/or localization. Alterations in the conformation of APC4 as compared with the smaller fragments might alter the accessibility of consensus phosphorylation sites or affect specificity for axonal kinases.

The data presented here indicate that fast anterograde axonal transport can be modulated specifically by factors that influence CDK-like kinases in the axon and suggest that the activity of axonal proline-directed kinases is important for regulating fast axonal transport.

\section{REFERENCES}

Allen RD, Metuzals J, Tasaki I, Brady ST, Gilbert SP (1982) Fast axonal transport in squid giant axon. Science 218:1127-1129.

Baeg GH, Matsumine A, Kuroda T, Bhattacharjee RN, Miyashiro I, Toyoshima K, Akiyama T (1995) The tumor suppressor gene product APC blocks cell cycle progression from G0/G1 to $\mathrm{S}$ phase. EMBO J 14:5618-5625.

Ballester R, Marchuk D, Boguski M, Saulino A, Letcher R, Wigler M, Collins FS (1990) The NF1 locus encodes a protein functionally related to mammalian GAP and yeast IRA proteins. Cell 63:851-859.

Beinhauer JD, Hagan IM, Hegemann JH, Fleig U (1997) Mal3, the fission yeast homologue of the human APC-interacting protein EB-1, is 
required for microtubule integrity and the maintenance of cell form. J Cell Biol 139:717-728.

Beroud C, Soussi T (1996) APC gene: database of germline and somatic mutations in human tumors and cell lines. Nucleic Acids Res 24:121-124.

Bhat RV, Baraban JM, Johnson RC, Eipper BA, Mains RE (1994) High levels of expression of the tumor suppressor gene APC during development of the rat central nervous system. J Neurosci 14:3059-3071.

Bhattacharjee RN, Hamada F, Toyoshima K, Akiyama T (1996) The tumor suppressor gene product APC is hyperphosphorylated during the M phase. Biochem Biophys Res Commun 220:192-195.

Bhattacharya G, Boman BM (1995) Phosphorylation of the adenomatous polyposis coli protein and its possible regulatory effects in cells. Biochem Biophys Res Commun 208:103-110.

Bloom GS, Richards BW, Leopold PL, Ritchey DM, Brady ST (1993) GTP $\gamma \mathrm{S}$ inhibits organelle transport along axonal microtubules. J Cell Biol 120:467-476.

Bollag G, McCormick F, Clark R (1993) Characterization of full-length neurofibromin: tubulin inhibits ras GAP activity. EMBO J 12:1923-1927.

Boulikas T (1995) Phosphorylation of transcription factors and control of the cell cycle. Crit Rev Eukaryot Gene Expr 5:1-77.

Boyer MJ, Gutmann DH, Collins FS, Bar-Sagi D (1994) Crosslinking of the surface immunoglobulin receptor in B-lymphocytes induces a redistribution of neurofibromin but not p120-GAP. Oncogene 9:349-357.

Brady ST (1993) Axonal dynamics and regeneration in neuroregeneration (Gorio A, ed), pp 7-36. New York: Raven.

Brady ST (1995) A kinesin medley: biochemical and functional heterogeneity. Trends Cell Biol 5:159-164.

Brady ST, Sperry AO (1995) Biochemical and functional diversity of microtubule motors in the nervous system. Curr Opin Neurobiol 5:551-558.

Brady ST, Lasek RJ, Allen RD (1982) Fast axonal transport in extruded axoplasm from squid giant axon. Science 218:1129-1131.

Brady ST, Lasek RJ, Allen RD, Yin H, Stossell T (1984) Gelsolin inhibition of fast axonal transport indicates a requirement for microfilaments. Nature 310:56-58.

Brady ST, Lasek RJ, Allen RD (1985) Video microscopy of fast axonal transport in isolated axoplasm: a new model for study of molecular mechanisms. Cell Motil 5:81-101.

Brady ST, Pfister KK, Bloom GS (1990) A monoclonal antibody against kinesin inhibits both anterograde and retrograde fast axonal transport in squid axoplasm. Proc Natl Acad Sci USA 87:1061-1065.

Burton PR, Page JL (1981) Polarity of axoplasmic microtubules in the olfactory nerve of the frog. Proc Natl Acad Sci USA 78:3269-3273.

Cicirelli MF, Pelech SL, Krebs EG (1988) Activation of multiple protein kinases during the burst in protein phosphorylation that precedes the first meiotic cell division in Xenopus oocytes. $\mathrm{J}$ Biol Chem 263:2009-2019.

Daston MM, Scrable H, Nordlund M, Sturbaum AK, Nissen LM, Ratner N (1992) The protein product of the neurofibromatosis type 1 gene is expressed at highest abundance in neurons, Schwann cells, and oligodendrocytes. Neuron 8:415-428.

Dobashi Y, Kudoh T, Matsumine A, Toyoshima K, Akiyama T (1995) Constitutive overexpression of CDK2 inhibits neuronal differentiation of rat pheochromocytoma PC12 cells. J Biol Chem 270:23031-23037.

Dobashi Y, Bhattacharjee RN, Toyoshima K, Akiyama T (1996) Upregulation of the APC gene product during neuronal differentiation of rat pheochromocytoma PC12 cells. Biochem Biophys Res Commun 224:479-483.

Ducommun B, Brambilla P, Felix MA, Franza BRJ, Karsenti E, Draetta $\mathrm{G}$ (1991) cdc2 phosphorylation is required for its interaction with cyclin. EMBO J 10:3311-3319.

Garner CC, Kindler S (1996) Synaptic proteins and the assembly of synaptic junction. Trends Cell Biol 6:429-433.

Golubic M, Roudebush M, Dobrowolski S, Wolfman A, Stacey DW (1992) Catalytic properties, tissue, and intracellular distribution of neurofibromin. Oncogene 7:2151-2159.

Gould KL, Moreno S, Owen DJ, Sazer S, Nurse P (1991) Phosphorylation at Thr167 is required for Schizosaccharomyces pombe p34-cdc2 function. EMBO J 10:3297-3309.

Gregory PE, Gutmann DH, Mitchell A, Park S, Boguski M, Jacks T, Wood DL, Jove R, Collins FS (1993) Neurofibromatosis type 1 gene product (neurofibromin) associates with microtubules. Somat Cell Mol Genet 19:265-274.
Groden J, Thliveris A, Samowitz W, Carlson M, Gelbert L, Albertsen H, Joslyn G, Stevens J, Spirio L, Robertson M (1991) Identification and characterization of the familial adenomatous polyposis coli gene. Cell 66:589-600.

Gu Y, Rosenblatt J, Morgan DO (1992) Cell cycle regulation of CDK2 activity by phosphorylation of Thr160 and Tyr15. EMBO J 11:3995-4005.

Heidemann SR, Landers JM, Hamborg MA (1981) Polarity orientation of axonal microtubules. J Cell Biol 91:661-665.

Hellmich MR, Pant HC, Wada E, Battey JF (1992) Neuronal cdc2-like kinase: a cdc2-related protein kinase with predominantly neuronal expression. Proc Natl Acad Sci USA 89:10867-10871.

Hirokawa N (1996) Organelle transport along microtubules: the role of KIFS. Trends Cell Biol 6:135-141.

Horii A, Nakatsuru S, Ichii S, Nagase H, Nakamura Y (1993) Multiple forms of the APC gene transcripts and their tissue-specific expression. Hum Mol Genet 2:283-287.

Hulsken J, Birchmeier W, Behrens J (1994) E-cadherin and APC compete for the interaction with $\beta$-catenin and the cytoskeleton. J Cell Biol 127:2061-2069.

Johnston KM, Brady ST, Kooy D, Connolly JA (1987) A unique tubulin antibody which disrupts particle movement in squid axoplasm. Cell Motil Cytoskeleton 7:110-115.

Joslyn G, Richardson DS, White R, Alber T (1993) Dimer formation by an N-terminal coiled coil in the APC protein. Proc Natl Acad Sci USA 90:11109-11113.

Lahey T, Gorczyca M, Jia XX, Budnik V (1994) The Drosophila tumor suppressor gene $d l g$ is required for normal synaptic bouton structure. Neuron 13:823-835.

Lasek RJ, Brady ST (1985) Attachment of transported vesicles to microtubules in axoplasm is facilitated by AMP-PNP. Nature 316:645-647.

Lew J, Huang QQ, Qi Z, Winkfein RJ, Aebersold R, Hunt T, Wang JH (1994) A brain-specific activator of cyclin-dependent kinase 5. Nature 371:423-426.

Lew J, Qi Z, Huang QQ, Paudel H, Matsuura I, Matsushita M, Zhu X, Wang JH (1995) Structure, function, and regulation of neuronal cdc2like protein kinase. Neurobiol Aging 16:263-268.

Martz D, Lasek RJ, Brady ST, Allen RD (1984) Mitochondrial motility in axons: membranous organelles may interact with the forcegenerating system through multiple surface binding sites. Cell Motil 4:89-102.

Matsumine A, Ogai A, Senda T, Okumura N, Satoh K, Baeg GH, Kawahara T, Kobayashi S, Okada M, Toyoshima K, Akiyama T (1996) Binding of APC to the human homolog of the Drosophila discs large tumor suppressor protein. Science 272:1020-1023.

McCormick F (1995) Ras signaling and NF1. Curr Opin Genet Dev 5:51-55.

McGuinness TL, Brady ST, Gruner J, Sugimori M, Llinás R, Greengard P (1989) Phosphorylation-dependent inhibition by synapsin I of organelle movement in squid axoplasm. J Neurosci 9:4138-4149.

Meijer L, Borgne A, Mulner O, Chong JP, Blow JJ, Inagaki N, Inagaki M, Delcros J-G, Moulinoux J-P (1997) Biochemical and cellular effects of roscovitine, a potent and selective inhibitor of the cyclin-dependent kinases cdc2, CDK2, and CDK5. Eur J Biochem 243:527-536.

Miller JR, Moon RT (1997) Analysis of the signaling activities of localization mutants of $\beta$-catenin during axis specification in Xenopus. J Cell Biol 139:229-243.

Miyashiro I, Senda T, Matsumine A, Baeg GH, Kuroda T, Shimano T, Miura S, Noda T, Kobayashi S, Monden M (1995) Subcellular localization of the APC protein: immunoelectron microscopic study of the association of the APC protein with catenin. Oncogene 11:89-96.

Moon RT, Miller JR (1997) The APC tumor suppressor protein in development and cancer. Trends Genet 13:256-258.

Morris J, Lasek RJ (1982) Stable polymers of the axonal cytoskeleton: the axoplasmic ghost. J Cell Biol 92:192-198.

Morris J, Lasek RJ (1984) Monomer-polymer equilibria in the axon: direct measurement of tubulin and actin as polymer and monomer in axoplasm. J Cell Biol 98:2064-2076.

Morrison EE, Askham J, Clissod P, Markham AF, Meredith DM (1997) Expression of $\beta$-catenin and the adenomatous polyposis coli tumor suppressor protein in mouse neocortical cells in vitro. Neurosci Lett 235:129-132.

Munemitsu S, Souza B, Muller O, Albert I, Rubinfeld B, Polakis P (1994) The APC gene product associates with microtubules in vivo and promotes their assembly in vitro. Cancer Res 54:3676-3681. 
Nathke IS, Hinck L, Swedlow JR, Papkoff J, Nelson WJ (1994) Defining interactions and distributions of cadherin and catenin complexes in polarized epithelial cells. J Cell Biol 125:1341-1352.

Nathke IS, Adams CL, Polakis P, Sellin JH, Nelson WJ (1996) The adenomatous polyposis coli tumor suppressor protein localizes to plasma membrane sites involved in active cell migration. J Cell Biol 134:165-179.

Nishisho I, Nakamura Y, Miyoshi Y, Miki Y, Ando H, Horii A, Koyama K, Utsunomiya J, Baba S, Hedge P (1991) Mutations of chromosome 5 q21 genes in FAP and colorectal cancer patients. Science 253:665-669.

Norbury C, Nurse P (1992) Animal cell cycles and their control. Annu Rev Biochem 61:441-470.

Nordlund M, Gu X, Shipley MT, Ratner N (1993) Neurofibromin is enriched in the endoplasmic reticulum of CNS neurons. J Neurosci $13: 1588-1600$

Ookata K, Hisanaga S, Okumura E, Kishimoto T (1993) Association of p34-cdc2/cyclin B complex with microtubules in starfish oocytes. J Cell Sci 105:873-881.

Park DS, Farinelli SE, Greene LA (1996) Inhibitors of cyclin-dependent kinases promote survival of postmitotic neuronally differentiated PC12 cells and sympathetic neurons. J Biol Chem 271:8161-8169.

Pfister KK, Wagner MC, Bloom GS, Brady ST (1989) Modification of the microtubule-binding and ATPase activities of kinesin by $\mathrm{N}$-ethylmaleimide (NEM) suggests a role for sulfhydryls in fast axonal transport. Biochemistry 28:9006-9012.

Polakis P (1995) Mutations in the APC gene and their implications for protein structure and function [review]. Curr Opin Genet Dev 5:66-71.

Pyles R, Groden J, Parysek LM (1998) Novel isoforms of the APC tumor suppressor in neural tissue. Oncogene 16:77-82.

Rowning BA, Wells J, Wu M, Gerhart JC, Moon RT, Larabell CA (1997) Microtubule-mediated transport of organelles and localization of $\beta$-catenin to the future dorsal side of Xenopus eggs. Proc Natl Acad Sci USA 94:1224-1229.

Rubinfeld B, Souza B, Albert I, Müller O, Chamberlain SH, Masiarz FR, Munemitsu S, Polakis P (1993) Association of the APC gene product with $\beta$-catenin. Science 262:1731-1734.

Rubinfeld B, Souza B, Albert I, Munemitsu S, Polakis P (1995) The APC protein and E-cadherin form similar but independent complexes with $\alpha$-catenin, $\beta$-catenin, and plakoglobin. J Biol Chem 270:5549-5555.

Rubinfeld B, Albert I, Porfiri E, Fiol C, Munemitsu S, Polakis P (1996) Binding of GSK $3 \beta$ to the APC- $\beta$-catenin complex and regulation of complex assembly. Science 272:1023-1026.

Santoro IM, Groden J (1997) Alternative splicing of the APC gene and its association with terminal differentiation. Cancer Res 57:488-494.

Shetty KT, Link WT, Pant HC (1993) cdc2-like kinase from rat spinal cord specifically phosphorylates KSPXX motifs in neurofilament pro- teins: isolation and characterization. Proc Natl Acad Sci USA 90:6844-6848.

Shetty KT, Kaech S, Link WT, Jaffe H, Flores CM, Wray S, Pant HC, Beushausen S (1995) Molecular characterization of a neuronalspecific protein that stimulates the activity of CDK5. J Neurochem 64:1988-1995.

Smith KJ, Levy DB, Maupin P, Pollard TD, Vogelstein B, Kinzler KW (1994) Wild-type but not mutant APC associates with the microtubule cytoskeleton. Cancer Res 54:3672-3675.

Stenoien DS, Brady ST (1997) Immunochemical analysis of kinesin light chain function. Mol Biol Cell 8:675-689.

Su L-K, Vogelstein B, Kinzler KW (1993a) Association of the APC tumor suppressor protein with catenins. Science 262:1734-1737.

Su L-K, Johnson KA, Smith KJ, Hill DE, Vogelstein B, Kinzler KW (1993b) Association between wild-type and mutant APC gene products. Cancer Res 53:2728-2731.

Su L-K, Burrell M, Hill DE, Gyuris J, Brent R, Wiltshire R, Trent J, Vogelstein B, Kinzler KW (1995) APC binds to the novel protein EB1. Cancer Res 55:2972-2977.

Takahashi M, Amin N, Grant P, Pant HC (1995) P13-suc1 associates with a cdc2-like kinase in a multimeric cytoskeletal complex in squid axoplasm. J Neurosci 15:6222-6229.

Thaler CD, Haimo LT (1996) Microtubules and microtubule motors: mechanisms of regulation. Int Rev Cytol 164:269-327.

Trzepacz C, Lowy AM, Kordich JJ, Groden J (1997) Phosphorylation of the tumor suppressor adenomatous polyposis coli (APC) by the cyclindependent kinase p34-cdc2. J Biol Chem 272:21681-21684.

Tsai LH, Delalle I, Caviness VSJ, Chae T, Harlow E (1994) p35 is a neural-specific regulatory subunit of cyclin-dependent kinase 5. Nature 371:419-423.

Vesely J, Havlicek L, Strand M, Blow JJ, Donella-Deana A, Pinna L, Letham DS, Kato J-Y, Detivaud L, Leclerc S, Meijer L (1994) Inhibition of cyclin-dependent kinases by purine analogues. Eur J Biochem 224:771-786.

Viskochil D, Buchberg AM, Xu G, Cawthon RM, Stevens J, Wolff RK, Culver M, Carey JC, Copeland NG, Jenkins NA (1990) Deletions and a translocation interrupt a cloned gene at the neurofibromatosis type 1 locus. Cell 62:187-192.

Wallace MR, Marchuk DA, Andersen LB, Letcher R, Odeh HM, Saulino AM, Fountain JW, Brereton A, Nicholson J, Mitchell AL, Brownstein BH, Collins FS (1990) Type 1 neurofibromatosis gene: identification of a large transcript disrupted in three NF1 patients. Science [Erratum (1990) 250:1749] 249:181-186.

Yost C, Torres M, Miller JR, Huang E, Kimelman D, Moon RT (1996) The axis-inducing activity, stability, and subcellular distribution of $\beta$-catenin is regulated in Xenopus embryos by glycogen synthase kinase 3. Genes Dev 10:1443-1454. 